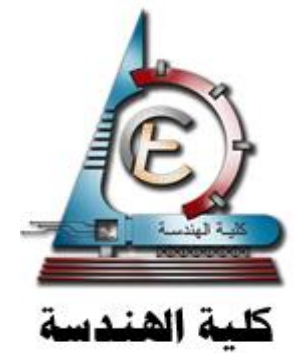

Journal of Engineering Sciences

Assiut University

Faculty of Engineering

Vol. 48, No. 6

Nov. 2020

PP. 1247 - 1261

\title{
FACTORS AFFECT PERFORMANCE MEASUREMENT IN CONSTRUCTION PROJECT PORTFOLIO
}

\section{Adel El-Samadony'; Hesham Abdelkhalek ${ }^{2}$; Diaa Khalaf ${ }^{3}$}

\footnotetext{
${ }^{I}$ Professor of Construction Engineering and Management- Civil Engineering

Department- Helwan University-Cairo,Egypt, ksamaster@epmcon.com

${ }^{2}$ Professor of Construction Engineering and Management-Civil Engineering

Department-Alexandria University-Cairo, Egypt, heshamkhaleq@gmail.com

${ }^{3}$ MSc Candidate Construction Project Management Faculty of Engineering Helwan

University-Cairo,Egypt.diaakhalaf@gmail.com
}

\begin{abstract}
Construction companies regularly perform multiple construction projects concurrently. Projects vary by complexity, duration, budget, variety of works, and the number of stakeholders. To determine and report the status of the ongoing portfolio of projects, methodical agreed-upon metrics should be set forth at both projects and portfolio level. The assessment of project indicators during implementation is not an easy task due to the lack of up-to-date data and factors measuring problems. The purpose of the research is to analyze common performance measurement factors, the contribution of those factors to the overall project portfolio performance, and to illustrate how to assess a projects' execution efficiency. A review for the earlier research and studies has been done to name the commonly used factors usually picked to measure the performance of portfolio and project management efficiency. A questionnaire survey conducted to project management professionals exploring their judgment in respect of relative weight contribution to each factor. AHP mathematical model used to analyses the survey responses.
\end{abstract}

Keywords: Construction Project portfolio, Performance measurement, AHP. 
1. List of Abbreviations:

AHP: Analytic Hierarchy Process. PPM: Project Portfolio Management MEF: Management Efficiency Factor RAF: Resource Allocation Factor SAF: Strategic Alignment Factor
CR: Consistency Ratio PPP: Project Portfolio Performance PPW: Project Priority Weight POP Project Overall Performance SD: Standard Deviation

\section{Introduction}

The term portfolio is associated with a collection of financial investment instruments, stocks, and bonds. However, this research does not try to address such types of portfolios. Instead, the area of concern encompasses project portfolio management and is hereafter referred to as PPM. Project Management is a tool for executing an overall organizational strategy. Therefore, it is inadequate to view project management only within the confines of the project. It must be considered within the context of the overall organization and its strategy. [1]. Included in this study is the positioning of project performance measurement of its (i) role in the management of projectrelated investments, as well as (ii) its role in contributing towards achieving the portfolio strategic objective. This research aims to analyze factors affecting the performance of construction projects.

\section{Problem statement}

It is shown from previous studies ([2] \& [3] [4] [5] [6] [7] [8]) that the failure of any project is mainly related to the problems and failure in performance. Moreover, there are many reasons and factors which contribute to this problem. Many construction projects fail without an early alert to the stakeholders. Besides, performance measurement systems are not effective or efficient to overcome this problem. Construction projects performance problem appears in different directions. Many constructed projects fail in time performance, others fail in cost performance, and others fail in other performance indicators. Therefore, this research will evaluate the factors affecting the performance of construction projects to improve the performance measurement ability of organizations while managing their construction projects in the context of portfolio management.

\section{Research Methodology}

Research based primarily on a literature review of factors affects project portfolio performance measurement. A conceptual model is proposed (Figure 1) with a two-level measurement, the project management efficiency 
performance level, and the project portfolio performance level. The contributions of each factor to the overall performance with each level will be evaluated. he hierarchy of project Portfolio performance factors shown in figure 1.

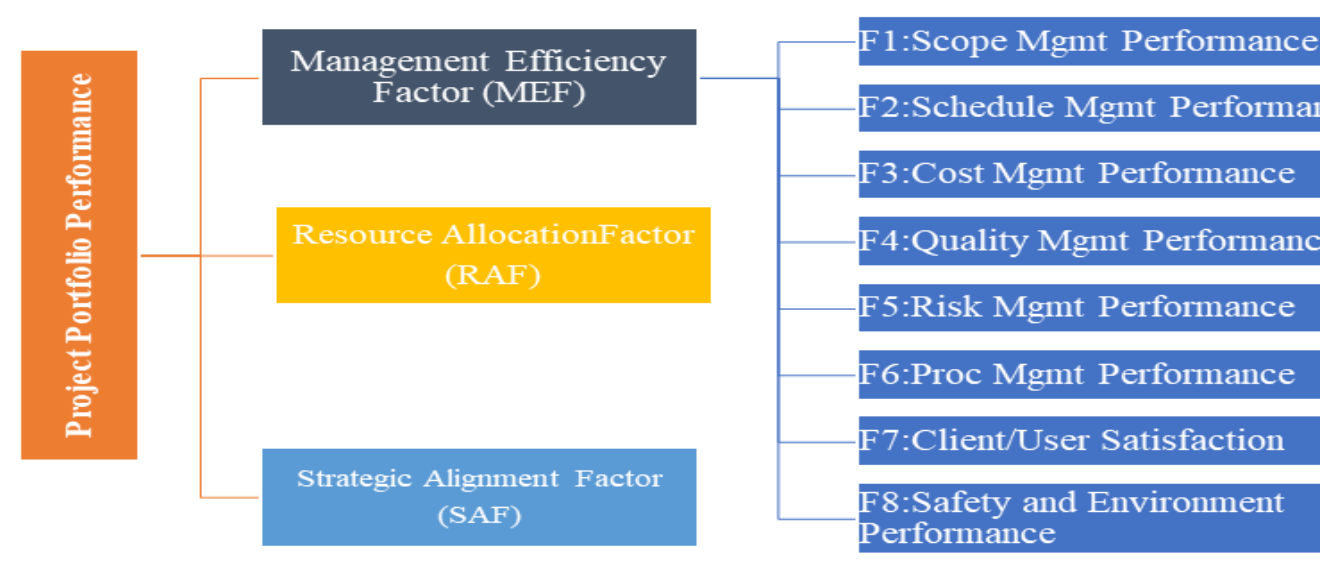

Figure 1: The proposed hierarchy of project Portfolio performance factors

The proposed model will assess the performance of the project portfolio using three performance factors;(1) Strategic Alignment Factor: measures to what extent the project still aligned with the business purpose that originally initiated., (2) Resource Allocation Factor: measures the organization's commitment to the allocation of project required resources. (3) Management Efficiency Factor; measure the overall performance of project management. At a project level, Management Efficiency Factor will be evaluated using eight performance factors: (1) Scope Management Performance, (2) Schedule Management Performance, (3) Cost Management Performance, (4) Quality Management Performance, (5) Risk Management Performance, (6) Procurement Management Performance, (7) Client/User Satisfaction, and (8) Safety and Environment Performance.

The survey questionnaire method used to produce a paired comparison for those factors. (Construction industry). The online survey conducted using an online surveying tool-the survey distributed in an online format through email to experts in the construction industry. Based on survey responses analysis, a comparison matrix constructed. Strategic Alignment Factor: measures to what extent still the project aligned with the business purpose that originally setup. It is determined through a survey of proper project management professionals, business unit managers, and executives. Resource Allocations' Factor: measure to what extent the organization committed to the 
allocation of project required resources. Management Efficiency Factor; measure the overall performance of project management.

Table 1 A nine-point scale for AHP analysis Saaty (1994)

\begin{tabular}{lll}
\hline Ratings & Definition & Intensity of importance \\
\hline 1 & Equal importance & $\begin{array}{l}\text { Two criteria/alternatives contribute equally to } \\
\text { the objective }\end{array}$ \\
\hline 2 & Weak & $\begin{array}{l}\text { Experience and judgment slightly favor one } \\
\text { criterion/alternative over another }\end{array}$ \\
\hline 3 & Moderate importance & Experience and judgment strongly favor one \\
\hline 5 & Moderate plus & criterion/alternative over another \\
\hline 6 & Strong importance & $\begin{array}{l}\text { A criterion/alternative is favored very strong } \\
\text { over another }\end{array}$ \\
\hline 7 & Strong plus & $\begin{array}{l}\text { The evidence favoring one } \\
\text { criterion/alternative over another }\end{array}$ \\
\hline 8 & Very strong importance & Is of the highest possible order of affirmation \\
\hline 9 & Extreme importance &
\end{tabular}

\section{Findings and analysis}

The experiential study was based on a questionnaire survey targeting construction industry experts. The questionnaire was created by using Lime Survey. The questionnaire was initially sent to more than 30 groups that include thousands of project management professionals; 216 individuals' access to the survey out of this group (40\%) fill in the complete survey- the survey organized into three parts. The first section was general questions regarding participants' experience and the environment of their respective organizations. In that part, three sets of questions were included to screen-and classify those interviewed based upon their role and work experience, the project for which they worked, and organization surroundings. Out of 80 , the full response, representing the population, (62.77\%) responded that they work in the construction industry. Those 62 answers only will be deemed as sample sizes for the subsequent analysis since research is focused on building firms. The respondents show a diversity of the roles they assigned in their organizations with several positions; Consultants (23\%), Senior Project Managers/Project Manager/Director (19\%), Head of Department (10\%), PMO Manager (8\%), Portfolio Manager/Director (8\%), and other positions like (Business/Operations Manager, Program Manager/Director, Business Change Manager, and Business Unit Director.) (32\%). Related to the project(s) durations, $48 \%$ of respondents are working on a project with an average duration of over two years, $31 \%$ managing projects in duration from 
1 to 2 years, $13 \%$ are working on projects 3 to six-month average duration. Over half of those responding to the questionnaire (56\%) demonstrates that they use General Individual Tools (i.e., Excel Spreadsheets, Word, Email.), and at the same time, managing their projects. Specialized Stand-alone Tools (i.e., Primavera P6 \& Ms. Project Standard,) used by 39\% of the organizations surveyed. While $40 \%$ of organizations use collaboration Tools (i.e., Web-based applications like Primavera P6 EPPM, MS Project Server, SharePoint server etc.., several of the organizations surveyed are using more than one type of tool; hence, the sum of the percentages to well over 100.

The following section examines the factor that is commonly used in organizations to measure Projects Management Efficiency per the respondents' company kind (i.e., the owner (or) owner representative, Architect/Engineer (Consultant), Contractor, Project Management). Figure 2 shows the percentage of surveyed firms in each role.
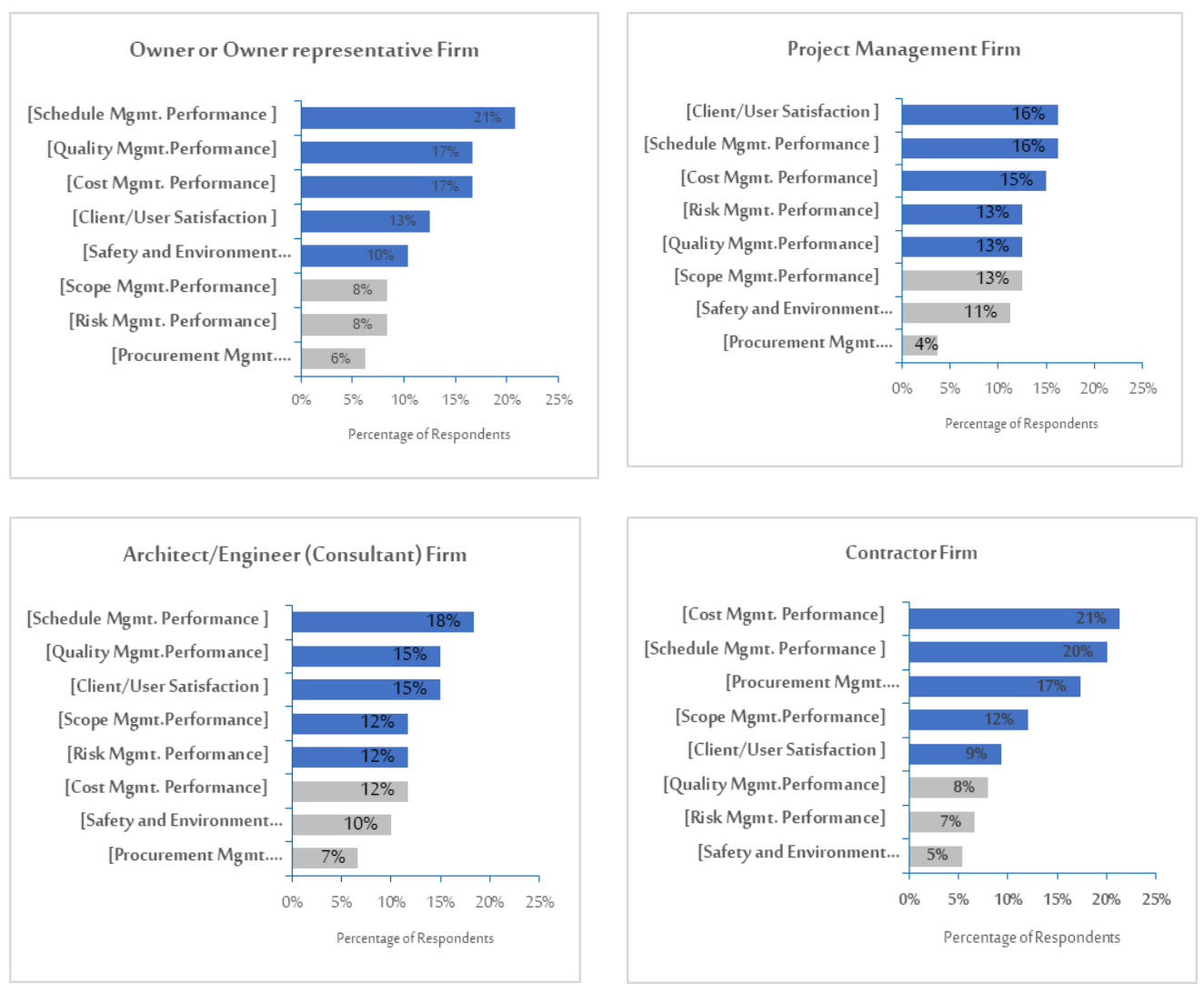

Figure 2: Factors routinely used in respondent's organization to measure Project Management Efficiency according to respondent's firm type 


\subsection{Calculating the eigenvectors and the consistency ratio (CR) for the Project Management Efficiency Factors}

The second part of the questionnaire was to determine the attribution of each management performance factor to the Project Management Efficiency Factors. In AHP this step is the calculation of a list of the relative weights, importance, or value, of the factors, such as cost and operability, which are relevant to the problem in question (technically, this list is called an eigenvector). The final stage is to calculate a Consistency Ratio (CR) to measure how consistent the judgments have been relative to large samples of purely random judgments. As shown in (figure 3), the questionnaire surveys the participants' preferences regarding each factor by pairwise questions.

\begin{tabular}{|c|c|c|c|c|c|c|c|c|c|c|c|c|c|c|c|c|c|c|}
\hline \multirow[t]{2}{*}{ With } & \multirow[b]{2}{*}{-9} & \multirow[b]{2}{*}{-8} & \multirow[b]{2}{*}{-7} & \multirow[b]{2}{*}{-6} & \multirow[b]{2}{*}{-5} & \multirow[b]{2}{*}{-4} & \multirow[b]{2}{*}{-3} & \multirow[b]{2}{*}{-2} & \multirow[b]{2}{*}{1} & \multirow[b]{2}{*}{2} & \multirow[b]{2}{*}{3} & \multirow[b]{2}{*}{4} & \multirow[b]{2}{*}{5} & \multirow[b]{2}{*}{6} & \multirow[b]{2}{*}{7} & \multirow[b]{2}{*}{8} & \multirow[b]{2}{*}{9} & \\
\hline & & & & & & & & & & & & & & & & & & \\
\hline $\begin{array}{l}\text { Scope Mgmt } \\
\text { Performance }\end{array}$ & 0 & & 0 & 0 & 0 & & & 0 & 0 & 0 & & & & & 0 & & & $\begin{array}{l}\text { Schedule } \\
\text { Mgmt } \\
\text { Performance }\end{array}$ \\
\hline $\begin{array}{l}\text { Scope Mgmt } \\
\text { Performance }\end{array}$ & & & & & & & & & & 0 & & & & & & & 0 & $\begin{array}{l}\text { Cost Mgmt } \\
\text { Performance }\end{array}$ \\
\hline $\begin{array}{l}\text { Scope Mgmt } \\
\text { Performance }\end{array}$ & 0 & 0 & 0 & 0 & 0 & 0 & 0 & 0 & 0 & 0 & 0 & 0 & 0 & 0 & 0 & 0 & 0 & $\begin{array}{l}\text { Quality Mgmt } \\
\text { Performance }\end{array}$ \\
\hline $\begin{array}{l}\text { Scope Mgmt } \\
\text { Performance }\end{array}$ & & & & & & & & & & & & & & & & & & $\begin{array}{l}\text { Risk Mgmt } \\
\text { Performance }\end{array}$ \\
\hline $\begin{array}{l}\text { Scope Mgmt } \\
\text { Performance }\end{array}$ & & & 0 & 0 & 0 & 0 & & 0 & & 0 & & & & & 0 & & & $\begin{array}{l}\text { Procurement } \\
\text { Mgmt } \\
\text { Performance }\end{array}$ \\
\hline $\begin{array}{l}\text { Scope Mgmt } \\
\text { Performance }\end{array}$ & & 0 & & & & & & & & 0 & & & & & & & & $\begin{array}{l}\text { Client/User } \\
\text { Satisfaction }\end{array}$ \\
\hline $\begin{array}{l}\text { Scope Mgmt } \\
\text { Performance }\end{array}$ & & 0 & 0 & 0 & & & & 0 & 0 & 0 & & & & & 0 & & & $\begin{array}{l}\text { Safety and } \\
\text { Environment } \\
\text { Performance }\end{array}$ \\
\hline
\end{tabular}

Figure 3: Sample of questionnaires' pairwise questions.

The questionnaire participants (total of 62) respond (individual Pairwise comparison) considered in the analysis. After calculating the respondent with the consistency ratio, CR $<0.15$ only taken into the aggregation. The rest of the calculations will consider only the 19 respondents $(C R<0.15)$.

Using $\mathrm{R}^{1}$ and "ahpsurvey ${ }^{2}$ " Package, the (ahp. aggjudge) function has been used to calculate Aggregate individual judgments from pairwise comparison matrices

\footnotetext{
${ }^{1} \mathrm{R}$ is a programming language and free software environment for statistical computing and graphics supported by the R Foundation for Statistical Computing.( https://en.wikipedia.org/wiki/R (programming_language)) ${ }^{2}$ https://cran.r-project.org/web/packages/ahpsurvey/vignettes/my-vignette.html
} 
the aggregated (from 19 matrixes) comparison matrix the as displayed in (Table 2).

Table 2 Aggregated comparison matrices for the 19 respondent that has $\mathrm{CR}<0.15$

\begin{tabular}{|c|c|c|c|c|c|c|c|c|}
\hline & 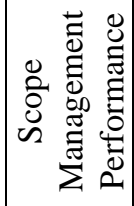 & 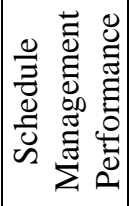 & 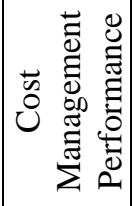 & 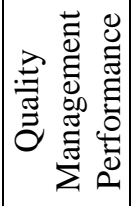 & 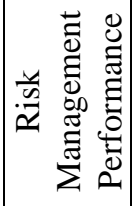 & 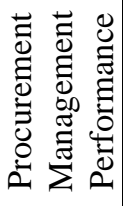 & 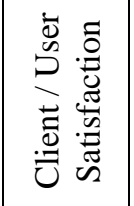 & 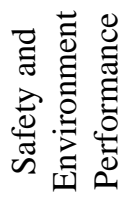 \\
\hline $\begin{array}{l}\text { Scope Management } \\
\text { Performance }\end{array}$ & 1 & 0.8581695 & 0.6271082 & 0.7772655 & 1.4095902 & 1.459185 & 0.681978 & 1.0442996 \\
\hline $\begin{array}{l}\text { Schedule } \\
\text { Management } \\
\text { Performance }\end{array}$ & 1.165271 & 1 & 0.6923826 & 1.1490066 & 1.0333958 & 2.045837 & 0.6448965 & 1.0541216 \\
\hline $\begin{array}{l}\text { Cost Management } \\
\text { Performance }\end{array}$ & 1.5946212 & 1.4442883 & 1 & 1.0579563 & 1.3904849 & 1.860183 & 0.880968 & 1.3952161 \\
\hline $\begin{array}{l}\text { Quality } \\
\text { Management } \\
\text { Performance }\end{array}$ & 1.2865616 & 0.870317 & 0.9452186 & 1 & 1.4582142 & 1.635915 & 0.7505327 & 1.0333958 \\
\hline $\begin{array}{l}\text { Risk Management } \\
\text { Performance }\end{array}$ & 0.7094261 & 0.9676835 & 0.7191736 & 0.6857703 & 1 & 1.383942 & 0.6850265 & 0.9504747 \\
\hline $\begin{array}{l}\text { Procurement } \\
\text { Management } \\
\text { Performance }\end{array}$ & 0.6853139 & 0.4887974 & 0.5375814 & 0.6112788 & 0.7225735 & 1 & 0.5116322 & 0.7354836 \\
\hline $\begin{array}{l}\text { Client / User } \\
\text { Satisfaction }\end{array}$ & 1.4663229 & 1.5506364 & 1.135115 & 1.3323869 & 1.4597975 & 1.954529 & 1 & 1.0298915 \\
\hline $\begin{array}{l}\text { Safety and } \\
\text { Environment } \\
\text { Performance }\end{array}$ & 0.9575796 & 0.9486572 & 0.7167349 & 0.9676835 & 1.0521059 & 1.35965 & 0.9709761 & 1 \\
\hline
\end{tabular}

Aggregate priority weights (Compute and aggregate individual priority weights from pairwise comparison matrices). The individual preference weights are computed using the Dominant Eigenvalues method described in Saaty (2003) [9]

Table 3 Project Management Efficiency Factors aggregated contributions and stander deviation

\begin{tabular}{|c|c|c|c|c|c|c|c|c|}
\hline Factor & 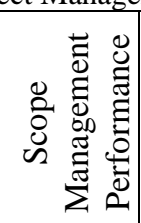 & 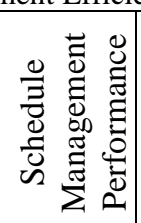 & 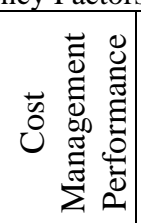 & 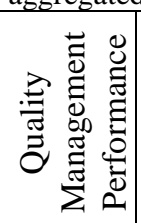 & 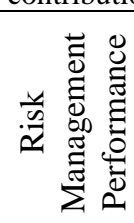 & 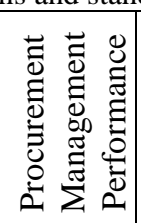 & 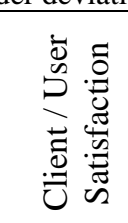 & 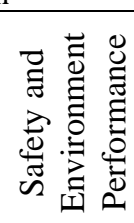 \\
\hline $\begin{array}{c}\text { Aggregat } \\
\text { ed }\end{array}$ & $\begin{array}{l}20746 \\
3\end{array}$ & $\begin{array}{c}0.124456 \\
4\end{array}$ & $\begin{array}{c}0.153042 \\
6\end{array}$ & $\begin{array}{c}0.123921 \\
1\end{array}$ & $\begin{array}{c}0.105667 \\
2\end{array}$ & $\begin{array}{c}0.077990 \\
9\end{array}$ & 72 & $\begin{array}{c}0.135203 \\
5\end{array}$ \\
\hline $\begin{array}{c}\text { Preferenc } \\
\text { es }\end{array}$ & $12.07 \%$ & $12.45 \%$ & $15.30 \%$ & $12.39 \%$ & $10.57 \%$ & $7.80 \%$ & $15.90 \%$ & $13.52 \%$ \\
\hline SD & $\begin{array}{l}081044 \\
4\end{array}$ & $\begin{array}{c}0.077126 \\
0\end{array}$ & $\begin{array}{c}0.102975 \\
8\end{array}$ & $\begin{array}{c}0.056995 \\
5\end{array}$ & $\begin{array}{c}0.060373 \\
6\end{array}$ & 0.04696 & 0.090757 & $\begin{array}{c}0.104686 \\
2\end{array}$ \\
\hline
\end{tabular}




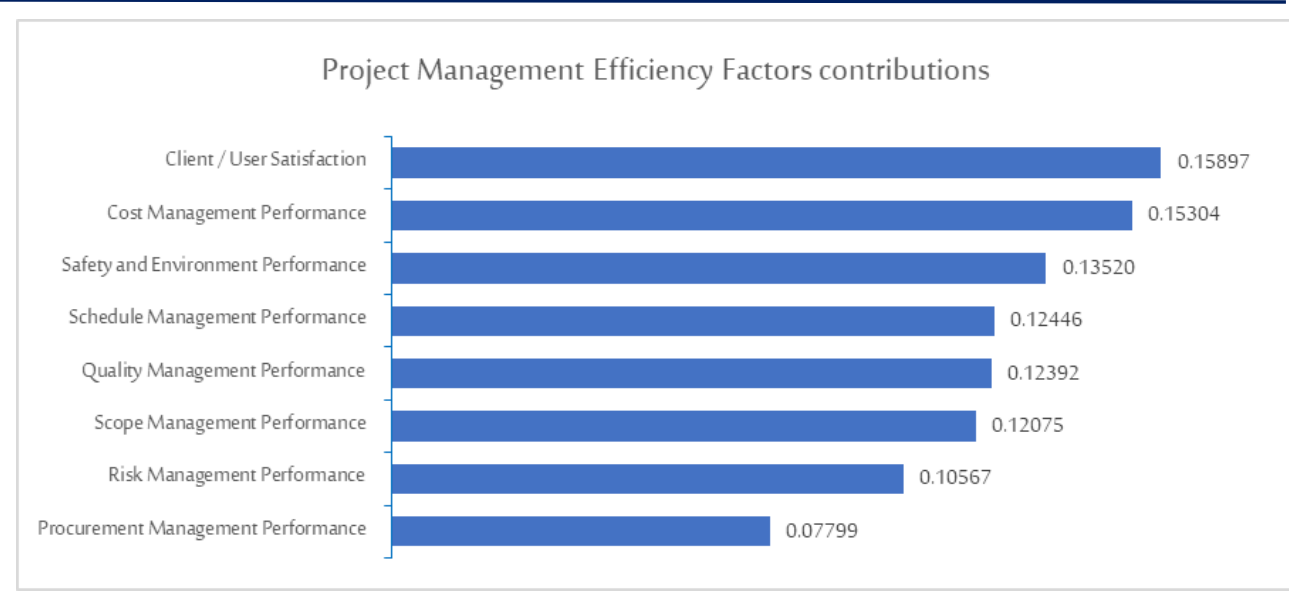

Figure 4 The contribution of each factor to the Project Management Efficiency.

\subsection{Calculating the eigenvectors and the consistency ratio (CR) for the Project Portfolio Performance.}

The last part of the questionnaire was to calculate the overall Project Portfolio Performance, and the following three factors have been considered.

1- Strategic Alignment Factor: measures to what extent the project still aligned with the business purpose that initially initiated.

2- Resource Allocation Factor: measures the organization's commitment to the allocation of project required resources.

3- Management Efficiency Factor; measure the overall performance of project management.

Part 3 of the questioner was to collect individuals' Pairwise comparison for these factors.

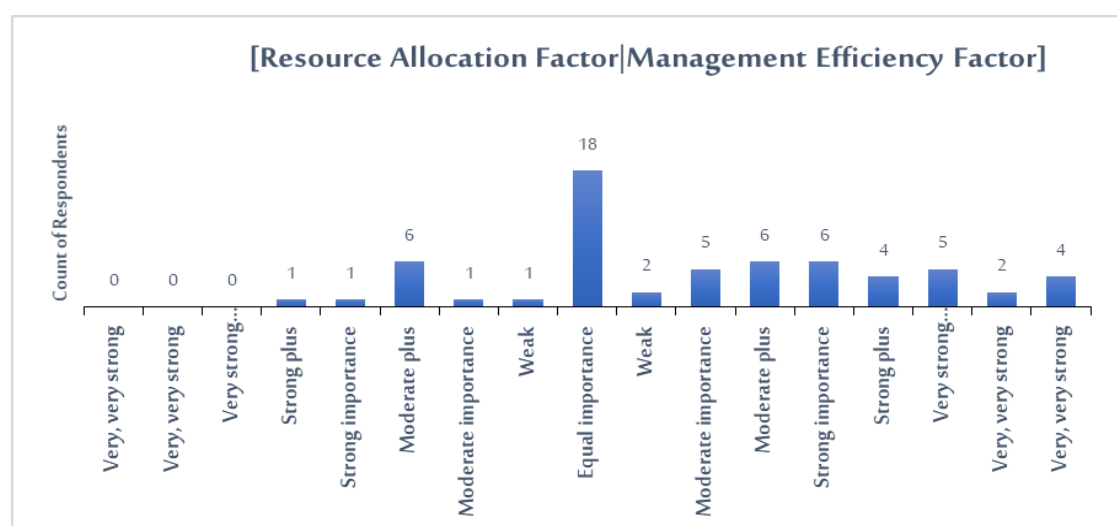

Figure 5 Respondent count for the comparison weight of Resource Allocation Factor and Management Efficiency Factor 
[Strategic Alignment Factor|Management Efficiency Factor]

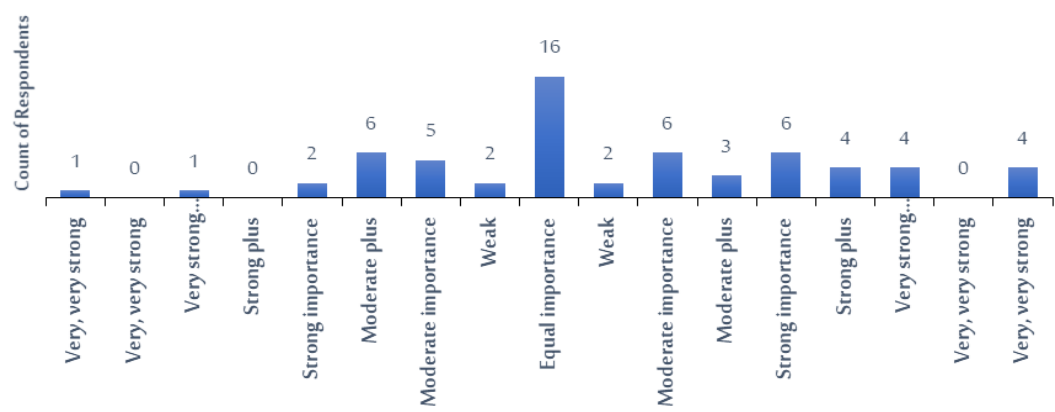

Figure 6: Respondent count for the comparison weight of [Strategic Alignment Factor and Management Efficiency Factor]

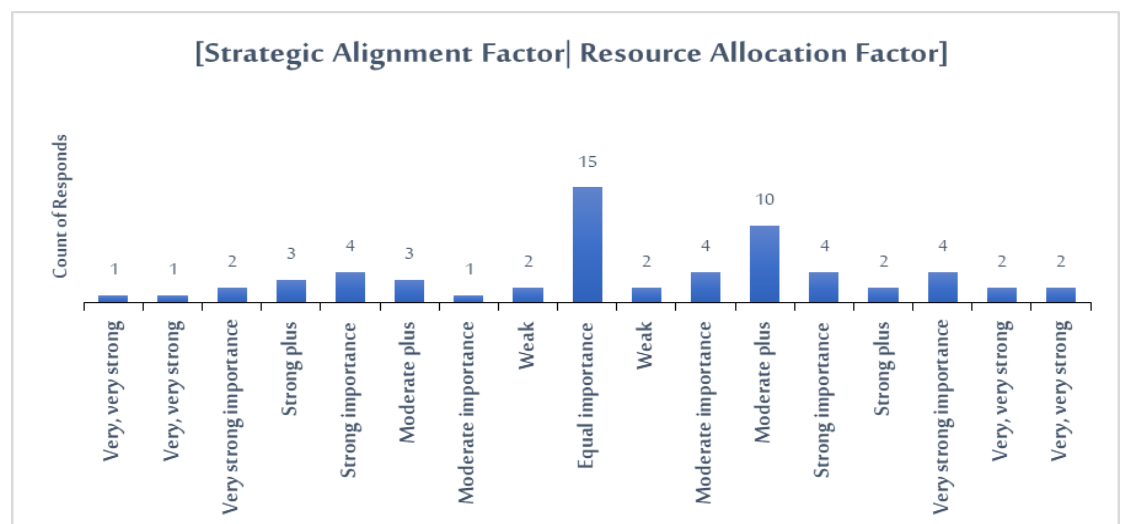

Figure 7: Respondent count for the comparison weight of Strategic Alignment Factor and Resource Allocation Factor

Based on it and using $\mathrm{R}$, the Individual priority weights of the decisionmakers have been calculated for each. Finally, the CR for each respondent calculated. Moreover, as per Saaty, all Respondent with $\mathrm{Cr}>0.1$ removed from the following calculation. Only 21 out of 62 responses have $\mathrm{Cr}<0.1$ and will be used for the rest of the analysis. Using R and "ahp survey" Package, the (ahp. aggjudge) function has been used to calculate Aggregate individual judgments from pairwise comparison matrices

Table 4 Aggregated comparison matrices for the 21 respondents with $\mathrm{CR}<0.1$

\begin{tabular}{|l|c|c|c|}
\hline & Strategic Alignment & $\begin{array}{c}\text { Resource } \\
\text { Allocation }\end{array}$ & $\begin{array}{c}\text { Management } \\
\text { Efficiency }\end{array}$ \\
\hline Strategic Alignment & 1.00 & 1.385757 & 0.8642102 \\
\hline Resource Allocation & 0.721627 & 1.00 & 0.5820066 \\
\hline $\begin{array}{l}\text { Management } \\
\text { Efficiency }\end{array}$ & 1.157126 & 1.718194 & 1.00 \\
\hline
\end{tabular}


Aggregate priority weights (Compute and aggregate individual priority weights from pairwise comparison matrices). The individual preference weights are computed using the Dominant Eigenvalues method described in Saaty (2003)

Table 5 Project Portfolio Performance factors aggregated contributions and stander deviation (SD)

\begin{tabular}{|l|c|c|c|}
\hline \multicolumn{1}{|c|}{ Factor } & $\begin{array}{c}\text { Strategic } \\
\text { Alignment }\end{array}$ & $\begin{array}{c}\text { Resource } \\
\text { Allocation }\end{array}$ & $\begin{array}{c}\text { Management } \\
\text { Efficiency }\end{array}$ \\
\hline Aggregated Preferences & 0.348418415 & 0.245974109 & 0.405607476 \\
& $(34.84 \%)$ & $(24.60 \%)$ & $(40.56 \%)$ \\
\hline $\begin{array}{l}\text { SD (Aggregated } \\
\text { Preferences) }\end{array}$ & 0.172259257 & 0.118605593 & 0.178519659 \\
\hline
\end{tabular}

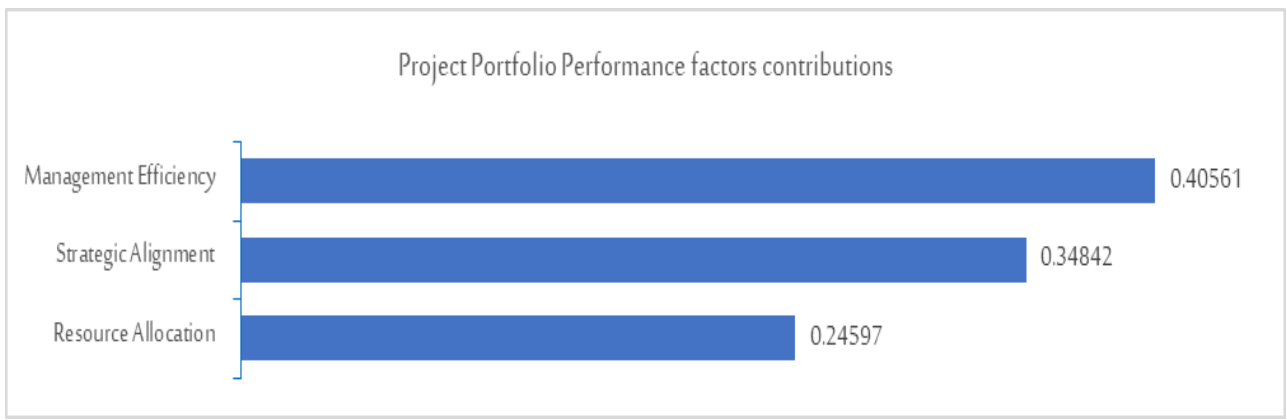

Figure 8 The contribution of each factor to the Project Portfolio Performance.

\subsection{Formulating Project Portfolio Performance (PPP) as a multi- attribute utility function in linear additive form}

The calculation of Project portfolio performance (PPP) will go through two main steps:

\subsubsection{Calculating the project management efficiency factor (MEF) for each portfolio component (project):}

As presented in the previous section, the result of the AHP analysis gives us the contribution of each project management efficiency factor to the overall project management factor. Table 6 .

The $P_{n \mathrm{Fi}}$ to be calculated as agreed by the organization, And the below equation will use to calculate the Management Efficiency Factor (MEF):

$$
\text { Management Efficiency Factor (MEF) } \mathrm{P}_{\mathrm{n} \text { MEF }}=\sum_{i=1}^{8} \mathrm{w}_{\mathrm{Fi}} \mathrm{P}_{\mathrm{nFi}}
$$

Figure $9 \& 10$ shows the output report scheme at project level using the research result. The upper and lower thresholds limit can be the same or different for each factor. 
Diaa Khalaf et al., Factors Affect Performance Measurement in Construction Project Portfolio

Table 6 Management Efficiency Factors (MEF)Contribution to the projects

\begin{tabular}{|c|c|c|c|c|c|c|c|c|c|}
\hline \multirow{2}{*}{ 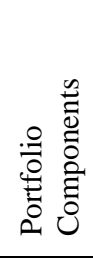 } & \multirow[t]{2}{*}{ 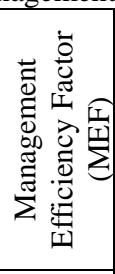 } & 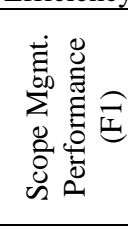 & 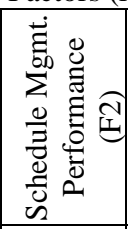 & 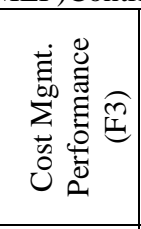 & 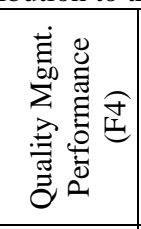 & 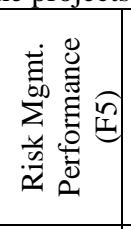 & 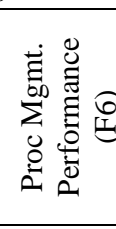 & 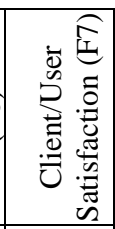 & 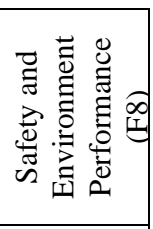 \\
\hline & & $12.07 \%$ & $12.45 \%$ & $15.30 \%$ & $12.39 \%$ & $7 \%$ & $7.80 \%$ & $15.90 \%$ & $13.52 \%$ \\
\hline $\mathrm{P}_{1}$ & $\mathrm{P}_{1 \mathrm{MEF}}$ & $P_{1 \mathrm{f} 1}$ & $P_{n f 2}$ & $P_{n f 3}$ & $P_{n f 4}$ & $P_{n f}$ & $\mathrm{P}_{\mathrm{n}}$ & $P_{n f 7}$ & $P_{n}$ \\
\hline $\mathrm{P}_{2}$ & 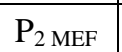 & $P_{2 \mathrm{f} 1}$ & $P_{2 \mathrm{f} 2}$ & $P_{2 f 3}$ & $P_{n f 4}$ & $P_{n f}$ & $P_{n}$ & $P_{n f 7}$ & $\overline{P_{n}}$ \\
\hline $\mathrm{Pn}$ & $\mathrm{n} \mathrm{MEF}$ & $P_{n f 1}$ & $P_{n f 2}$ & $P_{n f 3}$ & $P_{n f 4}$ & $P_{n f 5}$ & $P_{n f 6}$ & $P_{n f 7}$ & $P_{n f 8}$ \\
\hline
\end{tabular}

Project Management Efficiency Report

\begin{tabular}{|c|c|c|c|c|c|c|c|c|c|c|c|c|}
\hline \multicolumn{3}{|c|}{$\begin{array}{l}\text { Overall Management ttticiency factor } \\
\text { (MFF) }\end{array}$} & \multicolumn{2}{|r|}{$73.37 \%$} & & & & & & Date: & \multicolumn{2}{|l|}{ 1-Dec-2015 } \\
\hline \multirow[b]{2}{*}{ Portfolio Components } & \multirow{2}{*}{\multicolumn{2}{|c|}{$\begin{array}{l}\text { Projeect } \\
\text { Management } \\
\text { Efficiency Factor } \\
\text { (MFF) }\end{array}$}} & \multirow{2}{*}{\multicolumn{2}{|c|}{\begin{tabular}{c|c} 
Scope Mgimt \\
Performance (F1)
\end{tabular}}} & \multirow[b]{2}{*}{$\begin{array}{l}\text { Schedule Mimt } \\
\text { Performance (F2) }\end{array}$} & $15.30 \%$ & $12.39 \%$ & $10.57 \%$ & & $7.80 \%$ & $15.90 \%$ & $13.52 \%$ \\
\hline & & & & & & $\begin{array}{l}\text { Cost Mgmt } \\
\text { Performance (F3) }\end{array}$ & $\begin{array}{l}\text { Quality Mgmt } \\
\text { Performance (F4) }\end{array}$ & \begin{tabular}{c|} 
Risk Mggmt \\
Performance (F5)
\end{tabular} & \multicolumn{2}{|c|}{$\begin{array}{l}\text { Proc Mimt } \\
\text { Performance (F6) }\end{array}$} & $\begin{array}{c}\text { Client/User } \\
\text { Satisfaction (F7) }\end{array}$ & $\begin{array}{c}\text { Safety and } \\
\text { Environment } \\
\text { Performance (F8) }\end{array}$ \\
\hline Upper Threshold \% & & $80 \%$ & & $90 \%$ & $90 \%$ & $95 \%$ & $80 \%$ & $80 \%$ & & $80 \%$ & $95 \%$ & $90 \%$ \\
\hline Lower Threshold \% & & $70 \%$ & & $80 \%$ & $85 \%$ & $85 \%$ & $70 \%$ & $60 \%$ & & $60 \%$ & $90 \%$ & $85 \%$ \\
\hline Project 01 & 4 & $90 \%$ & P & $90 \%$ & $1 p \quad 100 \%$ & $\not \quad 80 \%$ & $p \quad 100 \%$ & $1>\quad 100 \%$ & p & $80 \%$ & $80 \%$ & $p \quad \mathbf{9 0} \%$ \\
\hline Project 02 & dg & $79 \%$ & p & $95 \%$ & $P \quad \mathbf{8 5} \%$ & $p \quad 30 \%$ & $p \quad 95 \%$ & $P \quad \mathbf{8 0} \%$ & p & $70 \%$ & $90 \%$ & $p \quad \mathbf{9 5} \%$ \\
\hline Project 03 & 8 & $77 \%$ & P & $60 \%$ & $69 \%$ & $80 \%$ & $P \quad \mathbf{7 5} \%$ & $70 \%$ & p & $75 \%$ & $90 \%$ & $90 \%$ \\
\hline Project 04 & $\rrbracket$ & $80 \%$ & P & $80 \%$ & $1 \quad 70 \%$ & $90 \%$ & $\not \quad 90 \%$ & $1 \quad 20 \%$ & p & $90 \%$ & $96 \%$ & $90 \%$ \\
\hline Project 05 & $\checkmark$ & $94 \%$ & P & $90 \%$ & $11 \quad 100 \%$ & $\triangleright \quad 95 \%$ & $\triangleright \quad 90 \%$ & $P \quad 100 \%$ & p & $95 \%$ & $1 \quad 95 \%$ & $P \quad \mathbf{9 0} \%$ \\
\hline Project 06 & $\checkmark$ & $85 \%$ & $P$ & $90 \%$ & $1 \nabla \quad 90 \%$ & $1 \quad 60 \%$ & $1 \quad 90 \%$ & $1 \quad 90 \%$ & $P$ & $70 \%$ & $\Vdash \quad 96 \%$ & $\$ \quad 90 \%$ \\
\hline Project 07 & 8 & $72 \%$ & P & $95 \%$ & $30 \%$ & $70 \%$ & $195 \%$ & $1 D \quad 30 \%$ & P & $70 \%$ & $1>\quad 80 \%$ & $95 \%$ \\
\hline Project 08 & \$ & $72 \%$ & P & $80 \%$ & $>\quad \mathbf{5 0} \%$ & $75 \%$ & $80 \%$ & $P \quad \mathbf{5 0} \%$ & p & $75 \%$ & $\triangleright \quad \mathbf{7 5} \%$ & $85 \%$ \\
\hline Project 09 & $x$ & $60 \%$ & p & $90 \%$ & $60 \%$ & F $60 \%$ & $1 \% \quad 1 \%$ & $60 \%$ & p & $60 \%$ & $P \quad 60 \%$ & $\triangleright \quad 90 \%$ \\
\hline Project 10 & $x$ & $69 \%$ & P & $80 \%$ & $1 \quad 70 \%$ & $55 \%$ & $\$ \quad 30 \%$ & $70 \%$ & P & $59 \%$ & $P \quad \mathbf{9 3} \%$ & $\Vdash \quad 90 \%$ \\
\hline Project 11 & 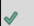 & $80 \%$ & P & $90 \%$ & $\triangleright \quad 100 \%$ & $\$ \quad 30 \%$ & $1 \quad 60 \%$ & $\triangleright \quad 90 \%$ & 1 & $90 \%$ & $\gg \quad \mathbf{9 5} \%$ & $\triangleright \quad 100 \%$ \\
\hline
\end{tabular}

Figure 9: Output report scheme at project level

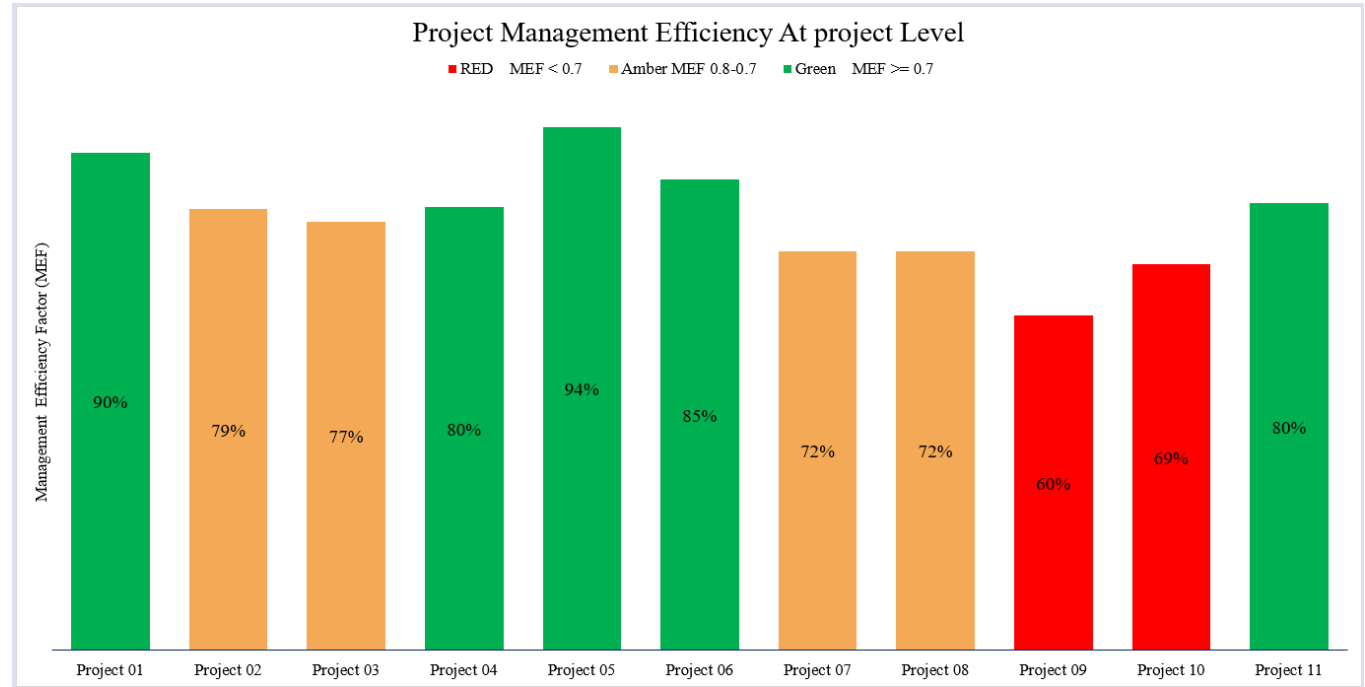

Figure 10: Project Management efficiency. 


\subsubsection{Calculating the overall project performance (POP) for each portfolio component (project):}

The portfolio Project portfolio performance factors that contribute to the overall performance of the project has been calculated. (Table 7)

Table 7 Project portfolio performance factors contribute to the overall performance of the project.

\begin{tabular}{|c|c|c|c|c|c|}
\hline $\begin{array}{l}\text { Portfolio } \\
\text { Component } \\
\text { s }\end{array}$ & $\begin{array}{c}\text { Project } \\
\text { Priorit } \\
y \\
\text { Weight }\end{array}$ & $\begin{array}{c}\text { Project } \\
\text { Overall } \\
\text { Performanc } \\
\mathrm{e}\end{array}$ & $\begin{array}{l}\text { Strategic } \\
\text { Alignmen } \\
\text { t Factor } \\
(\text { SAF })\end{array}$ & $\begin{array}{l}\text { Resource } \\
\text { Allocatio } \\
\text { n Factor } \\
\text { (RAF) } \\
\end{array}$ & $\begin{array}{l}\text { Managemen } \\
\text { t Efficiency } \\
\text { Factor } \\
(\mathrm{MEF})\end{array}$ \\
\hline & $(\mathrm{PPW})$ & (POP) & $34.84 \%$ & $24.60 \%$ & $40.56 \%$ \\
\hline $\mathrm{P}_{1}$ & $P_{1 \mathrm{ppw}}$ & $\mathrm{P}_{1 \mathrm{POP}}$ & $\mathrm{P}_{1 \mathrm{SAF}}$ & $\mathrm{P}_{1 \mathrm{RAF}}$ & $\mathrm{P}_{1 \mathrm{MEF}}$ \\
\hline $\mathrm{P}_{2}$ & $\mathrm{P}_{2} \mathrm{PW}$ & $\mathrm{P}_{2 \mathrm{POP}}$ & $\mathrm{P}_{2 \mathrm{SAF}}$ & $\mathrm{P}_{2 \mathrm{RAF}}$ & $\mathrm{P}_{2 \mathrm{MEF}}$ \\
\hline$P_{n}$ & $\mathrm{P}_{\mathrm{n} P W}$ & $\mathrm{P}_{\mathrm{n} \text { POP }}$ & $\mathrm{P}_{\mathrm{nSAF}}$ & $P_{\mathrm{n} R A F}$ & $P_{n}$ MEF \\
\hline
\end{tabular}

The $\mathrm{P}_{\mathrm{nSAF}} \& \mathrm{w}_{2} \mathrm{P}_{\mathrm{nRAF}}$ to be calculated as agreed by the organization, And the below equation will use to calculate the Project Overall Performance at portfolio level:

\section{Equation 1 Project Overall Performance $P_{n \text { POP }}=w_{1} P_{n S A F}+w_{2} P_{n \text { RAF }}+w_{3} P_{n M E F}$}

\subsubsection{Calculating the Project Portfolio Performance (PPP)}

The last step is the Project Portfolio Performance (PPP), and the below formula will be used

\section{Equation 2 Project Portfolio Performance PPP $=\sum_{i=1}^{n} P_{i \text { ppw }} \times P_{i \text { pop }}$}

The final output report scheme at the portfolio level shown in Figures $11 \&$ 12. The upper and lower thresholds limit can be the same or different for each factor. The Red, Yellow, and green method is used in the dashboard (Green = good, Yellow $=$ caution, Red $=$ bad). Also, the weight of each project can be considered as the column project priority weight (PPW) used for this purpose. 
Diaa Khalaf et al., Factors Affect Performance Measurement in Construction Project Portfolio

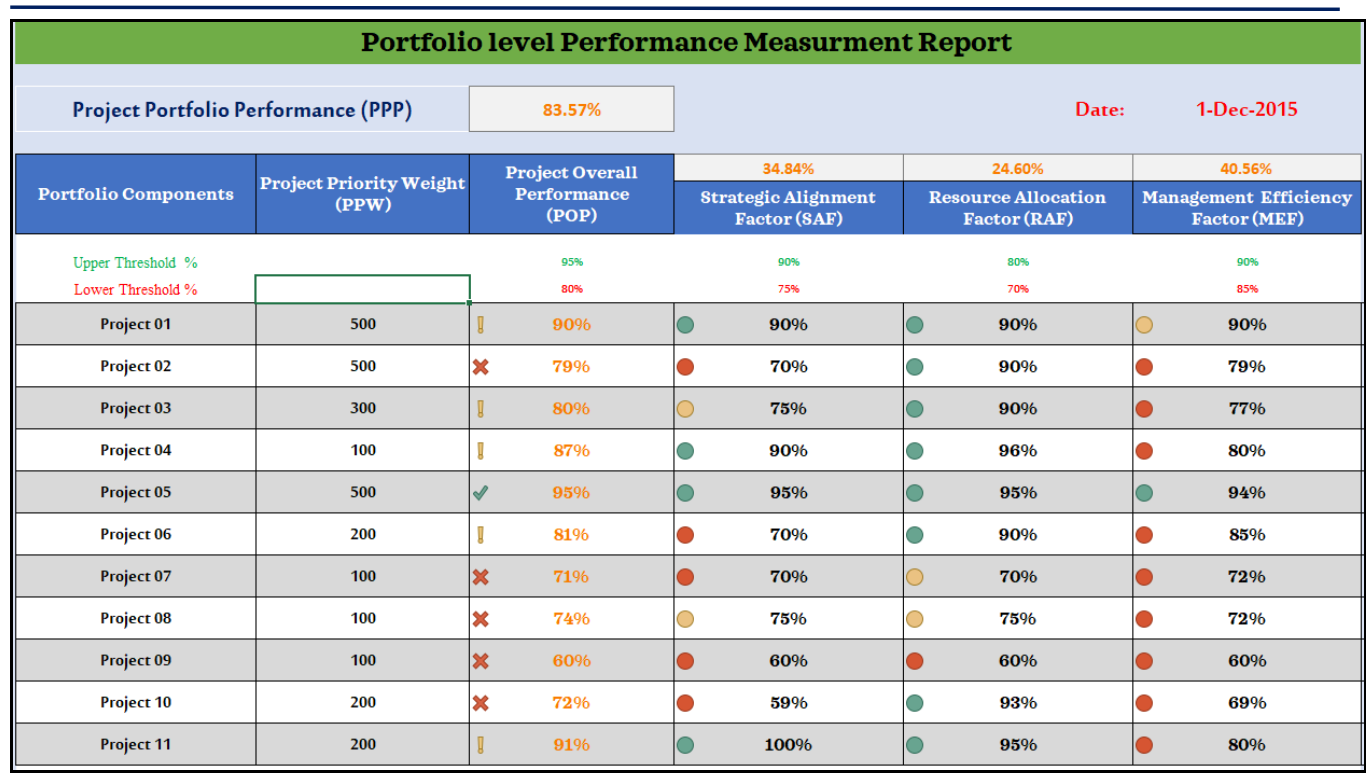

Figure 11 Output report scheme at portfolio level

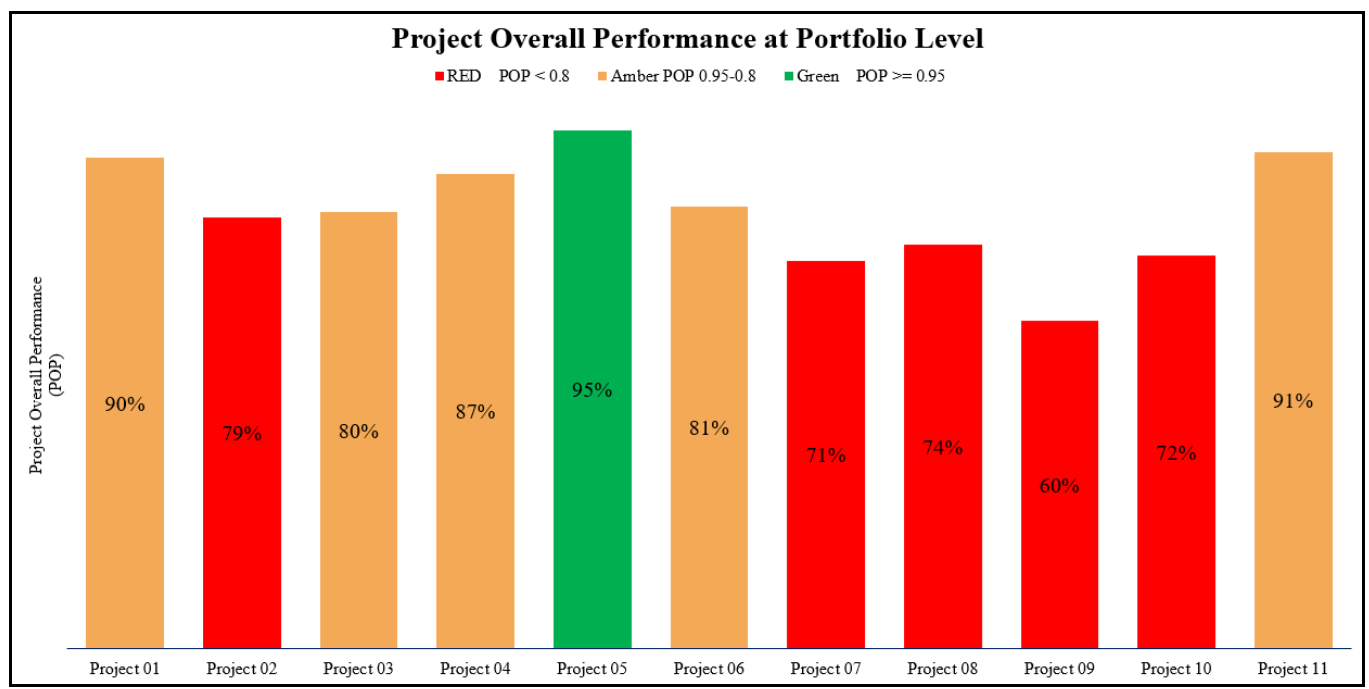

Figure 12: Project overall Performance at the portfolio level.

\section{Conclusion}

The emphasis of the research focused on the projects that are already selected and assigned to a specific portfolio and strive for identifying the performance and developing reporting structure that is applicable to current industry practice. Based on a questionnaire survey targeting construction industry experts, the study was performed. At the project level, the eight Project Management Efficiency factors listed during the literature review; Scope Management Performance (12.07\%) with standard deviation (0.0810444), 
Schedule Management Performance (12.45\%) with SD (0.0771260), Cost Management Performance (15.30\%) with SD (0.1029758), Quality Management Performance(12.39\%) with SD (0.0569955), Risk Management Performance $(10.75 \%)$ with SD (0.0603736), Procurement Management Performance(7.80\%) with SD (0.04696), Client/User Satisfaction(15.90\%) with SD (0.090757), and Safety and Environment Performance(13.52\%) with SD (0.1046862).

At the portfolio level, The last part of the questionnaire was to calculate the overall Project Portfolio Performance; the following three factors have been considered;(1)Strategic Alignment Factor (34.84\%) with SD (0.172259257); measures to what extent the project still aligned with the business purpose that initially initiated.,(2)Resource Allocation Factor (24.60\%) with SD (0.118605593); measures the organization's commitment to the allocation of project required resources.,(3)Management Efficiency Factor (40.56\%) with SD (0.178519659); measure the overall performance of project management.

\section{References:}

[1] David I. Cleland and WilliamR.King., Project Management Handbook, 2nd ed., D. I. a. W. R. King., Ed., Johan Wiely \&Sons, Inc., 1988 .

[2] A. Ahmad-Latiffi, "Performance measurement for construction businesses,", 2012. [Online]. Available: https://repository.lboro.ac.uk/articles/performance_measurement_for_construct ion_businesses/9456785. [Accessed 312 2019].

[3] M. Radujković, M. Vukomanović and I. B. Dunović, "Application of key performance indicators in South-Eastern European construction," Journal of Civil Engineering and Management, vol. 16, no. 4, pp. 521-530, 2010.

[4] H. A. E. M. Ali, I. A. Al-Sulaihi and K. S. Al-Gahtani, "Indicators for measuring performance of building construction companies in Kingdom of Saudi Arabia," Journal of King Saud University: Engineering Sciences, vol. 25, no. 2, pp. 125-134, 2013.

[5] L. O. Oyewobi, A. Windapo and J. O. B. Rotimi, "Measuring strategic performance in construction companies: a proposed integrated model," Journal of Facilities Management, vol. 13, no. 2, pp. 109-132, 2015.

[6] S. Kärnä and J. M. Junnonen, "Benchmarking construction industry, company and project performance by participants' evaluation," Benchmarking: An International Journal, vol. 23, no. 7, pp. 2092-2108, 2016.

[7] Susan S. Bivins \& Michael J. Bible, "Evaluating Strategic Project Portfolio Performance," PM World Journal, vol. I, no. III, October 2012 .

[8] The Enterprise Portfolio Management Council, PROJECT PORTFOLIO MANAGEMENT, New Jersey: John Wiley \& Sons, Inc., 2009, p. 39.

[9] T. L. Saaty, "Decision-making with the AHP: Why is the principal eigenvector necessary," European Journal of Operational Research, vol. 145, no. 1, pp. 8591, 2003. 


\section{العوامل المؤثرة على قياس اداء حافظات المشروعات الإنشائية}

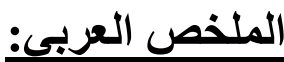

عادة ما تقوم شركات التشييد بتنفيذ مجمو عة من المشاريع في نفس الوقت ضمن

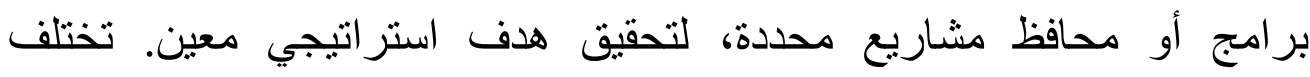

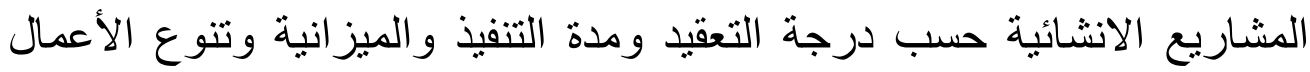

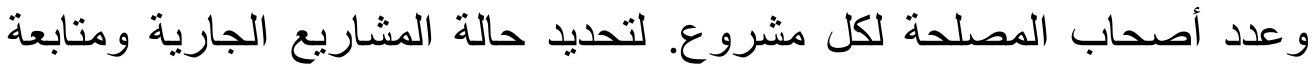

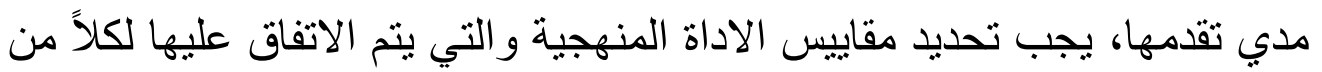
المشروع ومجموعة المشاريع او البر امج التي تقع ضمن محفظة مشاريع محددة.

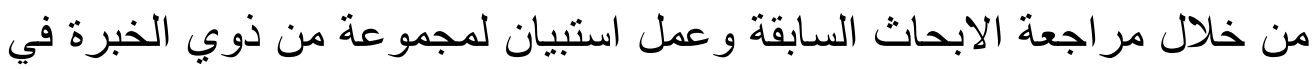
مجال التشييد والبناء ومن ثم تحليل نتائج الاستبيان باستخدام نموذج التحليل

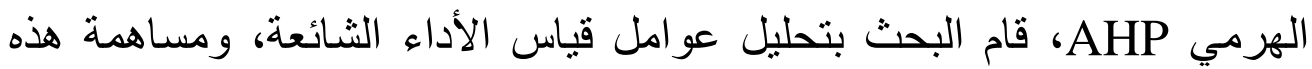
العو امل في الأداء العام لحافظة المشرو عات. و أيضاً تم توضيح كيفية تقييم كفاءة الأدية تتفيذ المشروع باستخدام النموذج المقتر ح بناءً على نتائج الدر اسة. 